\title{
Fieldwork: What Do TESL Trainee Teachers Benefit?
}

\author{
Nurul 'Ain Othman', Maslawati Mohamad1, Harieza Hussin², Nor Azilawati Mat Isa² \\ ${ }^{1}$ Faculty of Education, Universiti Kebangsaan Malaysia, Bangi, Malaysia \\ ${ }^{2}$ Pusat Citra, Universiti Kebangsaan Malaysia, Bangi, Malaysia \\ Email: nurulain@uthm.edu.my
}

Received 9 May 2016; accepted 26 July 2016; published 29 July 2016

Copyright (C) 2016 by authors and Scientific Research Publishing Inc.

This work is licensed under the Creative Commons Attribution International License (CC BY).

http://creativecommons.org/licenses/by/4.0/

(c) (i) Open Access

\begin{abstract}
How does real classroom experience provide essential experience for TESL trainee teachers? This paper illustrates the experience gained by TESL trainee teachers through classroom observation and in-depth interviews with the observed teachers. This study was conducted to fifteen secondyear TESL trainee teachers from the education faculty of University Kebangsaan Malaysia (UKM) who enrolled in the curriculum and pedagogy course. The trainee teachers observed and reflect teachers' teaching in schools. The findings showed that classroom observation is an important element in teacher training. It improves teacher trainees' knowledge of the job scope for English teachers at secondary level in Malaysia. Moreover, it could give them some clues and serve as guidelines on how to relate the lessons learned in the university to the real teaching practices. The findings could also help teacher training institutions to provide trainee teachers with pertinent information, knowledge and relevant skills to be effective and dynamic teachers.
\end{abstract}

\section{Keywords}

Classroom Management Strategies, Trainee Teachers, Teachers' Roles, Teaching Styles, Assessment toward Teaching Strategies

\section{Introduction}

It is very important for trainee teachers to experience teaching in real classroom environments to prepare them with the relevant knowledge and skills to be dynamic and effective teachers (Rosaline, 2011). The trainee teachers engaged in Teaching English as a Second Language (TESL) in the Faculty of Education, National University of Malaysia (UKM) must learn and apply the methods of teaching in the form of mini or micro teaching. Therefore, there is a need for these second-year TESL students to visit schools and observe how English teachers in 
the schools conduct their classes. This study was conducted to explore what these trainee teachers learnt in terms of the various types of teachers' roles in secondary schools.

This exercise is performed because trainee teachers should be prepared with relevant educational courses, as Jonas (2015) proposed that they need to be given a clearer picture of what the current needs and practices in schools and colleges are. By doing so, the trainee teachers could become effective teachers. Allowing only selected qualified teachers who had undergone different stages of training could help them to become effective teachers, thus benefiting the students (Darling Hammond, 2012). Trainee teachers should be made aware of teachers' roles in the classroom so that they can know what to expect when they start teaching, as the real situation might not develop as expected. They should also know when and how to apply the knowledge and methods learnt in the university within their classrooms, as Siti Salina and Lee Lai Fong (2008) proposed. According to these researchers, trainee teachers need to reflect on other teachers' teaching to see whether the methods used in the real classroom could help develop students' learning intellectually, morally and socially. They also suggested that trainee teachers could also learn more about classroom management and gain more knowledge and experience by discussing and working with other teachers.

\section{Literature Review}

\subsection{Theory of Social Studies}

This activity was conducted based on the theory of social studies. According to Bandura (1977), who developed this theory, people learn from others through observation, learning, copying and modelling. When people learn from others, they are influenced by what is happening around them. Whether they realise it or not, they actually copy what others are doing. This results in the inauguration and later retention of the actions copied. It is believed that in social learning system, people could acquire new behavioural pattern through direct experience or observing the behaviour of others. People have to face a lot of situations repeatedly and deal with them one way or another. During the process, they will find some of the responses to be successful or the other way round. This later will lead to the differential reinforcement process where people will select the successful strategies and discard the ineffectual ones.

Bandura also believed that most people are easily influenced by the behaviours of others. People learn by observing others' behaviour no matter how good or bad the influences are. Most of the behaviours that people display are learned, deliberately or inadvertently, through the influence of examples. A good example is said to be a much better teacher than the consequences of unguided actions.

In the case of this particular study, the trainee teachers learn about through observing teachers in schools. The trainee teachers had undergone the Methods in TESL course in the university making them to have some prior knowledge in teaching. Therefore, they go to secondary schools and observe English classrooms conducted by English teacher in the schools. Through their observation, they have learn on what are the roles of a teacher and making sense of what they learn in the university. The trainee teachers also learn on the classroom management strategies conducted by the teachers. The observation and learning through examples process helped the trainee teachers to understand better on teaching methods and serves as guidelines for their future endeavour.

\subsection{Teachers' Roles in Teaching English as a Second Language}

Harmer (2015) mentioned that a teacher not only is seen as a transmitter to transfer knowledge, but a teacher should also be able to create a lively learning environment. The lively environment promotes active learning, which makes learning more meaningful. He also stated that teachers could be perceived as facilitators, because they need to assist with students' activities in class. Teachers were also seen as controllers, in which capacity they take charge of the class during learning or other activities. Sometimes teachers also act as prompters in which they encourage students to think creatively and become more independent in their learning. Teachers also act as participants, especially in discussions, to encourage their students to be more confident in presenting ideas without being afraid of making mistakes. Teachers are also perceived as resources to which students could always refer if they come across any problems in the learning process. They also serve as tutors to teach and guide their students during the task completion. Teachers are often perceived as performers, because they have to perform in front of the audience to make the learning process entertaining and interesting. Teachers should know how to shift among their various roles depending on the situations and settings. 
In order to create a learning environment that can attract students' interest, teachers must be able to tackle the challenge of creating a pleasant environment in the classroom (Dewaele, 2014). Delaney et al. (2010) stated that effective teachers should learn and understand various personality traits such as diligence, friendliness, and tolerance in order to attract students' attention. Dornyei and Murphy (2003) also suggested that teachers should encourage students to get involved in the decision-making process, as this could help them adopt autonomous learning and help them enjoy the learning process even more.

\subsection{Reflective Practice}

Effective teachers need to improve their teaching skills and enhance their knowledge about teaching constantly. Reflective practice was one of the ways to help teachers to improve their teaching. Hanafi et al. (2014) stated that reflective practice was one of the most important elements in teaching, as it could serve as the bridge between practices and theories, thus contributing to better understanding about effective teaching. Reflective practice could also be used to help teachers to improve themselves and develop their knowledge. Rahimi (2008) stated that teachers' personal experiences and background knowledge were the key elements to teachers' development. He also claimed that self-assessment and reflective thinking were the ways to evaluate the teaching process.

Boyd and Harris (2010), on the other hand, suggested that reflective practice is " $a$ well-defined and crafted practice that carries very specific meaning and associated action." This perspective involves motivating to write down their daily encounters in the classroom. They added that reflection is only considered effective when teachers are able to make meaning from the situation so that they could comprehend the overall lessons to be learned.

Bulluogh and Gitlin (2013) agreed that an effective teacher should be able to think of his classroom practices and find ways to make adjustments and improvements to his teaching. Arthur-Kelly et al. (2013) asserted that reflective practitioners always take their time studying their innermost views about behaviours and manners and thus review their actions. This is not just reporting on what happened in class on a particular day; teachers should also note the causes of the activities they did in class. This is because effective reflection helps teachers to examine the reasons behind every action taken to develop understanding of the issues being investigated.

Effective teachers promote reflective practice, as it helps them evolve and better understand classroom management (Kiely, 2013). Goh and Matthews (2011) agreed that teachers could help enlighten issues pertaining to students' motivation, challenges encountered, and ways to overcome those challenges. Munirah and CheNoraini (2014) suggested that it triggers awareness and leads teachers to make changes in the way they teach. This will resulted in teachers to be more efficient in teaching. This effort is also parallel to the curriculum of teacher training in Malaysia, which focuses on autonomous learning. Ismail (2012) also believes that, if trainee teachers are able to understand the changes and improvements brought by reflective practice and apply them in their teaching, then the goal of education programmes to produce graduates with better understanding of teaching can be achieved.

\section{Methodology}

In this study, the trainee teachers were divided into small groups of two to three. Each group went to different secondary schools in Malaysia and observed English lesson conducted by English teachers. After that, the observed English teachers were interviewed by the trainee teachers. It is to determine teachers' role with regard to teaching methods and classroom management techniques in secondary schools. When they returned to the university, they presented their observations and participated in a discussion session with their classmates and lecturer. Then they started the screening process, during which they identified the teaching pedagogy that works best in multiple contexts. If they perceive any of the teaching pedagogy as ineffective, they discuss the reasons during their discussion. In doing so, the level of effectiveness of a teaching method could be measured by the trainee teachers.

This study uses a qualitative approach in order to focus more on the details of the phenomena from different perspectives and the meaning given from the perspective of respondents (Noraini, 2010). Researchers used focus group interviews (FGI), document analysis using the respondents' reflective notes (RN), and students' oral presentations (SOP). 


\subsection{Respondents}

\section{Trainee Teachers}

This qualitative study involved fifteen Teaching English as Second Language (TESL) trainee teachers from the in the Faculty of Education, National University of Malaysia (UKM). All of them were in their second year and registered in the curriculum and pedagogy course. Their age range is between 21 to 23 years old. As trainee teachers, they must learn and apply the methods of teaching in the form of mini or micro teaching. Therefore, in groups of two and three, they went to schools to observe and interview English teachers to gain as much information possible. Later, they prepared comprehensive reflective notes individually and submitted the notes to the researchers. Apart from that, they also prepared a 10 minutes presentation each to share on what have they learnt throughout their observation and interviews with the teachers.

\subsection{Oral Presentations (OP)}

Respondents were asked to provide an oral presentation on what have they learnt through their observations and engage in an interview session with the English teachers in school. The duration of their individual presentation was 10 minutes. The slides and script of their presentation were analysed to identify appropriate themes. Later, they were interviewed in focus groups.

\subsection{Focus Group Interviews (FGI)}

One of the instruments for a qualitative approach is through focus group interviews. Interview sessions were chosen so that researchers could further investigate and gain specific and clearer explanation and elaboration from the respondents. According to Morgan (1988), meaningful interviews could involve two or more people at a time. For the purpose of this study, the researchers used the focus group interview as a technique for collecting data. The face-to-face interview session involved the trainee teachers. In this particular study, the researchers used semi-structured interviews so that the respondents could give a detailed explanation and elaborate on their answers and opinions. There are three groups of respondents that have been interviewed. Each of the groups consists of 4 to 5 respondents. Each interview session lasted for 45 to 60 minutes. Focus group interviews were chosen so that respondents could get some ideas through their group members' responses during the interview session (Patton 1987). The researchers used this research tool so that the respondents would feel more comfortable answering the questions and to create a more relaxed atmosphere.

The interview session were recorded and were transcribed verbatim. Later, the respondents were asked to read the transcription and agreed to make some corrections (if there were any) to the transcription. The transcription was later coded. The data were analysed manually to develop appropriate themes. Respondents were marked with numbers 1 to 14 .

\subsection{Reflective Notes (RN)}

Creswell (1994) suggested that reflective notes could be made valuable in qualitative studies. Other than interviewing the English teachers observed, respondents also wrote reflective notes which were analysed for this study. Even though the respondents interviewed and observed the teachers in groups, the reflective notes must be written and prepared individually. The three-page reflective notes were also given as one of the assignments that needed to be submitted to the lecturer, who is also the researcher. In the reflective notes, respondents must attach the pictures taken throughout the interview sessions with the English teacher in school, with the use of teaching aids such as PowerPoint slides and whiteboards. The reflective notes were later evaluated. The total marks for reflective notes represented 10 percent. Marks were given to ensure that the respondents prepared comprehensive reflective notes.

\section{Findings and Discussion}

The findings indicate that the respondents have learnt about English teachers' roles in teaching and their classroom management strategies. They were also able to evaluate the teaching methods used by teachers to teach English in secondary schools. However, in this paper, the teachers' teaching methods are not discussed. 


\subsection{Teachers' Roles}

Teachers' roles were mentioned in all reflective notes, interviews, and oral presentations. Respondents could see the different roles of a teacher and why the teacher employed different approaches in teaching. There are three main roles of a teacher that have been reported: (1) Facilitator, (2) Expert in the field, and (3) Motivator.

a) Facilitator

As a facilitator, teachers do not make the class a teacher-centered lecture. Teachers explain concepts in detail and clarify matters that were not understood by the students using a few methods. The first method is through using dual language. This method is used especially when dealing with weak students to help them understand the concepts better. Here are the statements by 3 respondents (Respondent 1, 9 and 10) in the focus group interviews:

"Using dual language/code switching for weak students." (Respondent 1; FGI)

"Teacher used dual language because the students were from weaker class."

(Respondent 10; FGI)

Respondent 9, on the other hand, explained that, if English is used thoroughly, students will lose interest in learning because they will not understand what is being said by the teacher. The use of a dual-language technique (English and Malay) also helped the students to slowly understand and develop an interest in learning English.

During the focus group interview, Respondent 8 stated that teachers were also seen as facilitators when they answered students' questions in English despite being asked in Malay. The teacher demonstrated the meaning of the words using body language and giving an analogy. In addition, the teacher also drew pictures to give meaning to the words to facilitate visual learning. These correspond to Razianna (2005) who discovered that using Bahasa Malaysia in an English class has helped her respondents to learn English better as translation facilitates their comprehension of the English text.

\section{b) Expert in the field}

Respondents 8 and 9 stated in their reflective notes that the teacher used the drilling technique to train students in pronouncing words and sentences correctly. Respondent 3 mentioned in her oral presentation that the teacher used the Grammar Translation Method to translate an English poem in English into Malay. Meanwhile, Respondent 4 stated that the teacher corrects the mistakes made by the students directly and explains the mistakes made so that the students would not repeat the same mistakes in the future. Some of the mistakes that were commonly corrected were related to pronunciation and grammatical errors. The teacher asked the students to read poems to help improve their reading and poem recitation. Respondent 5 mentioned this in his presentation:

“Teacher asked the students to read poem to help improve reading skills. Teacher corrects the students' pronunciation"

The technique was also witnessed by Respondent 6 ("Teacher corrects students' pronunciation directly and prudently. She uses drilling technique for her students”). Respondent 6 also mentioned in his oral presentation that the meaning of words was explained using explanations that are relevant to the students' surroundings. Such feedbacks were said to help the students improve their English performance as Fathman and Walley (1990) in their study in multiple-draft settings showed that teacher feedback helped students improve their English performance especially in writing. In the absence of teacher feedback, ESL students showed improvement in the content of their revisions, but those who were given teacher feedback made greater improvements.

On the other hand, the demonstration technique was also used to help students understand the topic of the lessons. The Total Physical Response technique was also used during which the teacher acts as a model to the students, and instructions were given in English and students attempted to mimic the teacher. As the expert of this field, the teacher could identify the most appropriate method to be used for students of different ages and language proficiency levels as comprehensible input needs to be the key factor for teachers to keep learning meaningful (Krashen, 1981; Cakir \& Kafa, 2013).

\section{c) Motivator}

Motivation is one of the elements which drives the learners to excel. Motivation can be achieved when students are exposed to what they really enjoy. Experience shows that students are highly motivated when they are exposed to literary texts for language learning purposes (Khatib et al., 2011).

The teacher also plays the role as motivator by encouraging students to get involved in activities and conti- 
nuously praising them if they managed to complete the activity correctly. Motivating the students could help boost their confidence level in learning the language and improve their learning. Robitaille (2008) stated that teachers who are unmotivated and uninterested towards their subject are likely to have poor educational outcomes than teachers who are motivated and enthusiastic about their subject matter.

The teacher encourages the students to bring their own dictionary and write their own vocabulary notebooks (Respondent 10). As a motivator, teachers always encourage the students to continuously using English even though they have made mistakes in the sentences and pronunciations. As Respondent 1 stated in the interview,

"There are students who actively responding to the teacher despite using 'broken English'. This sure help the students build their confident level and slowly would help improving their English."

During the presentation, some of the respondents mentioned in all three research tools namely reflective notes, focus group interviews and oral presentations, teachers who encouraged their students to use English, but the students were not confident enough to use the language. The teacher then praised the students, even though they used the simplest English and made some grammatical mistakes. In order to encourage students' participation, a teacher has to be highly enthusiastic in teaching (Aregbeyen, 2010). A highly enthusiastic teacher will have better educational outcome (Robitaille, 2008).

\subsection{Classroom Management Strategies}

Other than teachers' role, respondents also witnessed the way teachers conducted their classrooms, especially in implementing discipline to the students. Classroom management relates to events that occurred in a classroom such as maintaining order and cooperation to prevent problems from arising; whereas disciplinary problems occurred in the act of handling and managing students' behavioural problems (Levin \& Nolan, 2000). Some of it occurred through the use of individual names to attract the students and help build good rapport as well as using positive and negative stimulation. The teacher should not stands statically but should move around the classroom to ensure that students are more disciplined, pay full attention, and give the teacher their full concentration and follow the teacher's instructions during the teaching and learning process. The teacher could also approach the weaker students and asked them to check their understanding.

"Teacher punished problematic students. Teacher also praised good students who at least tried to answer her questions." (Respondent 5; RN and OP)

"Teacher praised students who behaved in her class" (Respondent 9, FGI; RN, OP)

"Teacher called the students' name to get the attention and build good rapport" (Respondent 3; FGI, RN)

"Teacher managed to conduct the class well. Teacher moved in different directions to ensure that students were more disciplined. Teacher also approached students especially the weaker ones and asked whether or not they have any problems understanding" (Respondent 2; OP)

Respondents could see that to facilitate meaningful learning, teachers must learn about, see and experience successful learning-centred practices as teacher learning is usefully understood as a process of increasing participation in the practice of teaching, and through this participation, a process of becoming knowledgeable in and about teaching (Adler, 2000: p. 37)

Respondents also noticed that warnings should be made gradually. In the beginning, teachers will warn the students gently. However, if the warnings are ignored by the students, they should be punished to overcome discipline problems and to ensure that they do not disturb the others. It could also ensure that the learning process is more effective. Normally students who are bored will have the tendency to make noise.

"For those who always went out to the washroom and disturbing their friends, teacher will warn them gently at the beginning. If they still ignored the teacher, students will be punished in front of the whole class" (Respondent 9; FGI)

"There are also teachers who brought cane with them. This was meant to scares the students even though that the teachers did not use it against them. However, a more effective technique to make students pay more attention in class is through making the class more interactive and involving all of the students" (Respondent 10; OP)

"Teacher did not raise her voice even though that she had her cane with her. She made the class more interactive. Students pay more attention because they were afraid of making grammatical mistakes. They were afraid that their friend might laugh at them. (Respondent 2; FGI)

Therefore, the teacher should be well planned and conduct activities that would involve discussions to prevent students from chatting with their friends in class. Teachers should encourage students to get involved in the de- 
cision-making process, as this could help them adopt autonomous learning and help them enjoy the learning process even more (Dornyei \& Murphy, 2003).

To ensure that all students pay attention to the lesson and are not left behind, the teacher used the questioning technique for the weaker students. This technique was used to measure the level of understanding among the students. The teacher reported having to take some precautions to avoid misunderstanding among students.

"Teacher will ensure all students to ask questions especially to the weaker ones."

(Respondent 3; OP)

"The questions were asked to students especially to the weaker ones. If they failed to answer then teacher will repeat the lesson" (Respondent 14; OP)

"If students could not answer the questions, teacher will asked the students to try to understand and explain it to the whole class on what have they learnt on that day" (Respondent 4; FGI)

An effective teacher should be able to understand students' weaknesses and be more tolerance in order to attract students' attention (Delaney et al., 2010). Teacher should also know how to make adjustments and improvements to teaching so that it could cater students' needs (Bullough \& Gritlin, 2013).

In order to overcome vocabulary problems, the teacher asked the students to bring their own dictionary to class. If the students are having a hard time understanding and using the English-English dictionary, the teacher will encourage the students to use a dual-language dictionary. Students will be made aware that it was okay to use dual-language dictionary as it was also a good technique to learn second language (Razianna, 2005).

As Respondent 2 mentioned in his report, the teacher used the mentor-mentee technique. This approach represents a programme in which the student with a high language proficiency level helps students with low language proficiency. He also mentioned the same thing in his presentation and interview session.

Respondent 9 reacted in the report and during the interview session and mentioned a problematic student who caused trouble in class; the teacher later went to the student, patted his shoulder, and asked him to answer a question. Through this approach, problematic students could get the teacher's attention and teacher could help improve their English (Delaney et al., 2010).

\subsection{Assessment toward Teaching Strategies}

The findings indicated that students also had made some assessments of the teaching strategies and activities conducted in class. For example, as Respondent 1 wrote in his report, the teacher was witnessed ignoring a student who does not follow her instruction to pick up her chair. This caused the student to lose focus and lack concentration in class. The respondent reported that the teacher should have personally confronted the student and warned him, since the teacher acts as the guardian to the students. This was also discussed during the focus group interview. Some of the other respondents also expressed the same view. Respondents 5 and 14 stated that,

"Teacher should take some action towards the student who did not pay attention in class as this would also affected the other students. It could be a bad influence to the other students as they will easily lose focus and missed the lesson. The best is for the teacher to advise the students individually" (Respondent 5; FGI)

"Teacher should have called the students who was not paying attention and playing outside of the class. Teacher should not abandon the student because gradually they will lose interest to learn" (Respondent 14; FGI)

Through the assessments, respondents could see that teacher have the chance to construct and reconstruct their own knowledge. They could diagnose and understand their classroom contexts and students' learning better, put their students' learning at the heart of the teaching-learning process, develop a rationale for their teaching and take informed specific actions and make sound decisions in the classroom (Al-Issa, 2002). The observations have also generate a reciprocal benefit for both the observed and the observing teachers (Al-Issa et al., 2010).

Many respondents made assessment of the use of English between the teacher and students in class. Most of the respondents mentioned in the interview and report that the teacher should have used English more during the teaching and learning process to expose the students to the language. This is because the students could learn new vocabularies and also learn how to use them. Students could also learn how to pronounce words correctly from the teacher throughout the lesson. Respondents also commented on how students should be encouraged to use English as much as possible to help them boost their confidence to use the language. This can be facilitated through group discussions and so on. Confidence is very important, as many would feel embarrassed if they mispronounce words or make grammatical mistakes. Teachers on the other hand should not focus too much on the 
students' mistakes, as it would not help boost their confidence. Some of the responses gained from Respondents 3, 8 and 11 in their reflective notes and focus group interviews are,

"Teacher encourages students to use English. However, students till use Malay language. Students felt that teachers should stressed out the importance of using English in class. It is because it is the only time and chance for the students to use English. Teachers should use English at the same time encouraging the students to use it. Some might feel ashamed of using English because they are not confident of using it but teacher should show good examples to them." (Respondent 3 , RN)

"Teachers should asked the students to discuss in groups on what do they understand about the poem. No answer should be given to the students" (Respondent 8; FGI)

"It would be much better if both students and teachers uses as much English possible in class as the students could learn a lot of new vocabularies, improve pronunciations and increase the level of confidence in speaking English" (Respondent 11; RN, FGI)

These help respondents to get clearer picture on how teaching should be done. Respondents also learn that motivating students is as important as installing the knowledge. Students will be more confident in using English if the teacher keeps on encouraging them despite their weaknesses in using the language (Razianna, 2005).

A few respondents also suggested in the reflective notes that more teaching techniques should be integrated in the teaching so that teachers could be more versatile and increase the fun level by learning the language and helping students to understand better. This suggestion were also repeated by Respondents 10 and 13 during the interview session,

"If only one teaching technique were implemented, there are possibilities that only good students could enjoy it the most. Advanced students would feel bored and weak students will be left out and missed the lesson" (Respondent 10; FGI)

"Creative teachers are those who use variety of teaching techniques. Students could enjoy the lesson more" (Respondent 13; FGI)

Similarly, a research conducted by Pauline and Bobbie (2011) on 16 teacher trainees from the Sultan Idris Education University Malaysia has found that many participants documented concerns about their own teaching activities and performances. They wrote about trying to improve their teaching performance and the need for adequate preparation. This shows that the respondents realise their responsibilities in making teaching more meaningful.

The findings highlighted that the respondents assessed the various techniques the teachers needed to apply when teaching English so that the learning process could be made more fun and interesting as well as increase students' proficiency level. Moreover, the respondents stated that students need to learn actively and get involved directly in the learning process. A learner-centred approach is better than a teacher-centred approach and is crucial to enhance students' level of understanding despite the different learning techniques that they have. Some of the respondents' suggestions were to use a sense of humour in the classroom, advise the students to bring their own dictionary to school, ask them to find the meaning of words they do not understand in the dictionary, encourage repetition, and use a vocabulary note book. Repetition is a process during which the teacher repeats the points taught so that the students can remember better. The vocabulary note book on the other hand will enable the students to write down the new words they encountered that day. Students could write the meaning of the words and explain how to use the words in sentences in the note book. This could help them better to remember the word.

"Teacher makes jokes in class. I find it very interesting. I am very confident that the students really enjoyed the lesson with the approach used" (Respondent 2; SGI, RF)

"Teacher asked the students to find the meaning of words in the dictionary. This technique involved the students more in the lesson and they were no longer bored in class" (Respondent 9; SGI, OP)

"Students found that the vocabulary note book as something very interesting because they could learn a lot of new words and get to learn how to use the words. They could also remember the words better" (Respondent 5; OP, RF, SGI)

"Teacher-centred classroom and Grammar Translation Method does not give the students a lot of chances to speak English. In order to help enhancing the level of proficiency of the students, they need to be exposed as much as possible to the language" (Respondent 11; OP)

"Other than interpreting the poem, teacher should have asked the students to have a discussion session in groups to discuss on what do they understand about the poem. Answers should not be given to the students" (Respondent 12; RN, SGI) 
The result was very similar to a case study conducted by Kabilan and Raja Izzaham (2008) on the challenges faced and the strategies adopted by a female English language teacher during teaching practice. The respondents were found to have used strategies which draw upon their effective pedagogical knowledge and practices to overcome challenges faced during teaching and these include; experimenting through trial and error of theories and ideas, understanding the challenges, being determined, persistent and perseverant and encouraging, prompting and motivating.

There are two more techniques that the respondents thought were effective, which are reflection and drilling. When doing reflection, students will try to understand and recall what they learnt in the previous class. Drilling, on the other hand, would require the students to repeat over and over what had been learnt in the previous class. The respondents thought that both are very good techniques that could help the students to learn, understand, and remember better as highlighted using all research tools.

"Teacher asked the students to recall what have been learnt in the previous meeting. It is a very good technique as the teacher could check on the students understanding towards the subject matter." (Respondent 2; SGI, $\mathrm{OP})$

"Drilling is effective as it could help the students to improve on their pronunciation. The teacher herself has used the same technique and felt the improvement" (Respondent 6; RN, OP)

Through reflection, teachers and teacher trainee were enable to diagnose and understand their classroom contexts and students' learning better, put their students' learning at the heart of the teaching-learning process, develop a rationale for their teaching and take informed specific actions and make sound decisions in the classroom (Al-Issa, 2002). It is because teaching is a scholarly activity and is about learning through systematic critical reflection, which can influence learning, understanding, induction of conceptual change, knowledge transfer and action positively (Strampel \& Oliver, 2007). Furthermore, Borko (2004) has identified that the materials, lesson plans, sample of students' work enabled teachers to reflect on their own practice and work for improvement. If the materials or resources were too difficult, they were simplified or adapted, if they were successfully used, they were shared. These were reflected in Glathorn (1990; as cited in Rosaline, 2011) who stressed that teachers want learning opportunities that are meaningful and practical to them, offer an immediate pay-off and involving reflection on their many experiences.

\section{Conclusion}

Preparing trainee teachers with the relevant knowledge and skills to be dynamic and effective teachers were not easy. As far as the trainee teachers are concerned, there are a lot of matters to be considered if they want to be effective teachers. Effective teachers should know their roles as teachers and fulfil them effectively to ensure that students have a better learning environment and help boost students' confidence and motivation to learn. Effective teachers should also know how to manage the classroom and use appropriate methods in teaching so that they are able to understand the students better. They should also reflect more on their teaching styles so that they can improve their teaching skills and identify the issues encountered by students that could affect their teaching quality. This study indicates that by conducting a field work at schools, trainee teachers have learnt a lot especially on the diverse teachers' roles, classroom management strategies so as teaching strategies. Trainee teachers also learnt that through reflective teaching, they could gain a lot of information that could help them improve their teaching and knowledge about teaching (Al-Issa, 2002). It is hoped that the findings of this study could provide both trainee teachers and lecturers on related area to teach more effectively and benefit their students.

\section{Implication of the Study}

This study has several implications especially for the trainee teachers. Trainee teachers could enhance their knowledge of the various English teachers' roles at secondary level in Malaysia. Furthermore, they could also see the importance of relating the lessons learned in the university and the real teaching practices. The findings are also very useful for teacher training institutions to prepare trainee teachers with classroom management and teaching strategies as the strategies differ according to students' background, knowledge, proficiency level and learning styles. This relevant knowledge and skills are significant to produce dynamic and effective teachers. It is hoped that the findings of this study could serve as guidelines for both trainee teachers and teacher training institutions. 


\section{References}

Adler, J. (2000). Social Practice Theory and Mathematics Teacher Education: A Conversation between Theory and Practice. Nordic Mathematics Education Journal, 8, 31-53.

Al-Issa, A. (2002). An Ideological and Discursive Analysis of English Language Teaching in the Sultanate of Oman. Unpublished Doctoral Dissertation. University of Queensland.

Al-Issa, A., \& Al-Bulushi, A. (2010). Training English Language Student Teachers to Become Reflective Teachers. Australian Journal of Teacher Education, 35. http://dx.doi.org/10.14221/ajte.2010v35n4.4

Aregbeyen, O. (2010). Students' Perceptions of Effective Teaching and Effective Lecturer Characteristics at the University of Ibadan, Nigeria. Pakistan Journal of Social Sciences, 7, 62-69. http://dx.doi.org/10.3923/pjssci.2010.62.69

Arthur Kelly, M., Sutherland, D., Lyons, G., Macfarlane, S., \& Foreman. P. (2013). Refletions on Enhancing Pre-Service Teacher Education Programmes to Support Inclusion: Perspectives from New Zealand and Australia. European Journal of Special Needs Education, 28, 217-233. http://dx.doi.org/10.1080/08856257.2013.778113

Bandura, A., \& Walters, R. H. (1977). Social Learning Theory.

Borko, H. (2004) Professional Development and Teacher Learning: Mapping the Terrain. Educational Researcher, 33, 3-15.

Boyd, P., \& Harris, K. (2010). Becoming a University Lecturer in Teacher Education: Expert School Teachers Reconstructing Their Pedagogy and Identity. Professional Development in Education, 36, 9-24. http://dx.doi.org/10.1080/19415250903454767

Bullough, R., \& Gitlin, A. (2013). Becoming a Student of Teaching. Linking Knowledge Production and Practice (2nd ed.), New York: Routledge Falmer.

Çakir, I., \& Kafa, S. (2013). English Language Teachers’ Preferences in Presenting Target Language Grammar. Dilve Edebiyat Egitimi Dergisi, 2, 39.

Creswell, J. W. (1994). Research Design: Qualitative and Quantitative Approaches. Thousand Oaks. CA: Sage.

Darling-Hammond, L. (2012). Powerful Teacher Education: Lessons from Exemplary Programs. San Francisco: John Wiley \& Sons.

Delaney, J., Johnson, A. N., Johnson, T. D., \&Treslan, D. L. (2010). Students’ Perceptions of Effective Teaching in Higher Education. Memorial University of Newfoundland. Distance Education and Learning Technologies.

Dewaele, J. M. (2014). It Takes Two to Tango: The Dynamic Interaction of Emotional and Psychological Aspects in Foreign Language Learning. ETAS Journal. The Magazine for English Professionals, 31, 51-53.

Faizah, A. M. (2008). The Use of Reflective Journals in Outcome-Based Education during the Teaching Practicum. Malaysian Journal of ELT Research, 4, 32-42.

Fathman, A. K., \& Whalley, E. (1990). Teacher Response to Student Writing: Focus on Form versus Content. In B. Kroll (Ed.), Second Language Writing: Research Insights for the Classroom (pp. 178-190). Cambridge: Cambridge University Press.

Goh, P. S., \& Matthews, B. (2011). Listening to the Concerns of Student Teachers in Malaysia during Teaching Practice. Australian Journal of Teacher Education, 36, Article 2.

Hanafi, M., \& Hashim, C. N. (2014). Exploring Pre-Service Student Teachers' Experiences on Reflective Practice. Scottish Journal of Arts, Social Sciences and Scientific Studies, 2, 22-30.

Harmer, J. (2015). The Practice of English Language Teaching. London: Pearson.

Ismail, H., Hassan, R., Konting, M. M., \& Wan Ali, W. Z. (2012). Comparing Teachers’ Aspiration towards Change in Teaching and Learning and Their Actual Classroom Practices. Pertanika Journal of Social Sciences \& Humanities, 20, 259-270.

Jonas, H. (2015). Drawing the Boundary Lines of Science Education: Subject Associations and Swedish Pre-Service Biology Teacher Education 1960-1990. History of Education Review, 44, 219-235.

Kabilan, M. K., \& Raja Izzaham, R. I. (2008). Challenges Faced and the Strategies Adopted by a Malaysian English Language Teacher during Teaching Practice. English Language Teaching, 1, 87-95. http://dx.doi.org/10.5539/elt.v1n1p87

Khatib, M., Rezaei, S., \& Derakhshan, A. (2011). Literature in EFL/ESL Classroom. English Language Teaching, 4, 201. http://dx.doi.org/10.5539/elt.v4n1p201

Kiely, R. (2013). Integrating Reflection in Teacher Education: Guidelines for Practice.

Levin, J., \& Nolan, J. F. (2000). Principles of Classroom Management: A Professional Decision-Making Model. Boston, MA: Allyn and Bacon.

Munirah, H., \& CheNoraini, H. (2014). Exploring Pre-Service Student Teachers’ Experiences on Reflective Practice. Scottish Journal of Arts, Social Sciences and Scientific Studies, 21, 22-30. 
Rahimi, M. (2008). What Do We Want Teaching-Materials for in EFL Teacher Training Programs? Asian EFL Journal, 31, $1-35$.

Razianna, A. R. (2005). Learning English from Learners' Perspective. In Proceedings Seminar Penyelidikan Pendidikan Kebangsaan ke XII 2005. Putrajaya: Kementerian Pelajaran Malaysia.

Robitaille, C. A. (2008). Emotional Intelligence and Teachers: An Exploratory Study of Differences between General and Special Education Teachers. Ph.D. Dissertation, OH: Union Institute and University.

Rosaline, E. (2011). How Untrained Teachers Develop Their Teaching Skills and Perceive Themselves as Second Language Teachers-A Case Study in Malaysia. Doctoral Thesis, Leicester: University of Leicester.

Siti Salina, G., \& Lee, L. F. (2008). Linking Theory and Practice: The Case of TESL Trainee Teachers. Asian Journal of University Education, 4, 1-34.

Strampel, K., \& Oliver, R. (2007). Using Technology to Foster Reflection in Higher Education. In ICT: Providing Choices for Learners and Learning. Proceedings Ascilite Singapore (pp. 973-982).

\section{Submit or recommend next manuscript to SCIRP and we will provide best service for you:}

Accepting pre-submission inquiries through Email, Facebook, LinkedIn, Twitter, etc. A wide selection of journals (inclusive of 9 subjects, more than 200 journals)

Providing 24-hour high-quality service

User-friendly online submission system

Fair and swift peer-review system

Efficient typesetting and proofreading procedure

Display of the result of downloads and visits, as well as the number of cited articles

Maximum dissemination of your research work

Submit your manuscript at: http://papersubmission.scirp.org/ 